\title{
Morphological analysis of micropyrite populations from the Toarcian of Bulgaria
}

\section{Морфологичен анализ на микропиритни популации от Тоарския етаж в България}

\author{
Lubomir Metodiev ${ }^{1}$, Tanya Stoylkova ${ }^{2}$, Milena Georgieva ${ }^{2}$, Elena Koleva-Rekalova ${ }^{1}$ \\ Любомир Методиев ${ }^{1}$, Таня Стоилкова ${ }^{2}$, Милена Георгиева ${ }^{2}$, Елена Колева-Рекалова ${ }^{1}$ \\ ${ }^{1}$ Geological Institute, Bulgarian Academy of Sciences, Acad. G. Bonchev Str., Bl. 24; 1113, Sofia, Bulgaria; \\ E-mails: lubo@geology.bas.bg, e_koleva@geology.bas.bg \\ ${ }^{2}$ Sofia University "St. Kliment Ohridski”, Department of Mineralogy, Petrology and Economic Geology, \\ 15 Tzar Osvoboditel Blvd., 1504 Sofia, Bulgaria; E-mails: milena@gea.uni-sofia.bg, tstoilkova@gea.uni-sofia.bg
}

\begin{abstract}
Morphological analysis of micropyrite populations of argillaceous inner shelf deposits from the Toarcian of Bulgaria was carried out in order to evaluate their stratigraphic distribution and their potential as recorders for redox conditions. Four types of micropyrites were documented: 1) euxinic framboids; 2) oxic/dysoxic framboids; 3) polyframboids; and 4) non-framboidal diagenetic pyrites. Resedimented sulphides were also observed. Micropyrite morphologies denoted upper- to lower dysoxic depositional settings within the sampled successions. Anoxic conditions seem also possible to exist but at very narrow intervals.
\end{abstract}

Keywords: micropyrite populations, framboids, morphology, Toarcian, Bulgaria.

Pyrite framboids are a common diagenetic mineral phase in organic-rich mudrocks, and are particularly characteristic of sediments formed under oxygenrestricted depositional settings (see Wignall et al., 2005 and references therein). Framboids are densely-packed, raspberry-like, subspheroidal aggregates of equigranular pyrite microcrysts that may range in size from a few microns to several tens of microns. As stated by Wilkin et al. (1996), framboids that were formed under euxinic bottom waters are, on average, smaller and less variable in size than framboids of sediments underlying dysoxic water column. Framboid morphological analysis and sizefrequency measurements are valuable techniques for recognizing the presence of oxygen-stagnant conditions in sedimentary environments, and many good examples of this exist in the literature (e.g., Wignall et al., 2005; Bond, Wignall, 2010; Rickard, 2019). In Bulgaria, efforts in this regard have recently been made by Pugh (2018), who found abundant framboids present in the lower Toarcian strata of several different stratigraphic sections. Framboid occurrences were interpreted to be indicative of predominantly oxic/dysoxic and limitedly of anoxic/euxinic conditions (ibid.). This account aims to present the preliminary results of investigation on framboids from new stratigraphic levels and successions of the Bulgarian Toarcian. The statistical analysis of framboid populations will be given in details elsewhere.

For this study, we have selected 3 stratigraphic sections of the Toarcian from Western Bulgaria that correspond to the Bukorovtsi Member of the Ozirovo Formation: 1) section Dobravitsa-1;2) section Bov; and 3) borehole section C-3 Belotintsi (for location see Fig. 1a). Oxygenated to poorly oxygenated bottom water conditions have previously been indicated in the lower Toarcian rocks of sections Dobravitsa-1 and Bov (Pugh, 2018; Metodiev et al., 2020). These successions are typical examples of markedly condensed Toarcian sediments of the Western Balkan Mts area. Section C-3 Belotintsi is a $150 \mathrm{~m}$-thick subsurface Toarcian succession in the Montana Depression (Western Fore-Balkan 
Mts). It is being currently investigated, but at least a few levels of stagnant conditions could also be inferred in both the lower and the upper Toarcian. A total of 30 bulk samples were collected for framboid analysis. Samples were selected from mud-rich lithologies assigned below, within and above stratigraphic intervals with supposed oxygen-deficient conditions. From each sample, a $2 \times 2 \times 1 \mathrm{~cm}$ block was mounted in epoxy resin, then grounded to a maximum planar surface and finally polished with diamond compound $1 / 10 \mu \mathrm{m}$. Mounted blocks were carbon coated and viewed under a Scanning Electron Microscope (SEM) Jeol JSM-GO10PLUSILA at the University of Mining and Geology "St Ivan
Rilski”, Sofia (Bulgaria). SEM analysis (backscattered electron images, BSE, at $150 \times$ to $6000 \times$ magnification, and EDS elemental measurements) was carried out to determine pyrite content and to recognize the key allochems and mineral phases. The samples were examined for a total of $27 \mathrm{hrs,} \mathrm{with}$ duration of analysis between $30 \mathrm{~min}$ and $1 \mathrm{hr} 30$ min per sample, depending on the framboid abundance. The framboid populations were categorized morphologically as recommended by Wignall and Newton (1998), and Bond and Wignall (2010).

BSE investigation revealed highly variable micropyrite abundances in each of the sampled stratigraphic sections. Four informally designated types
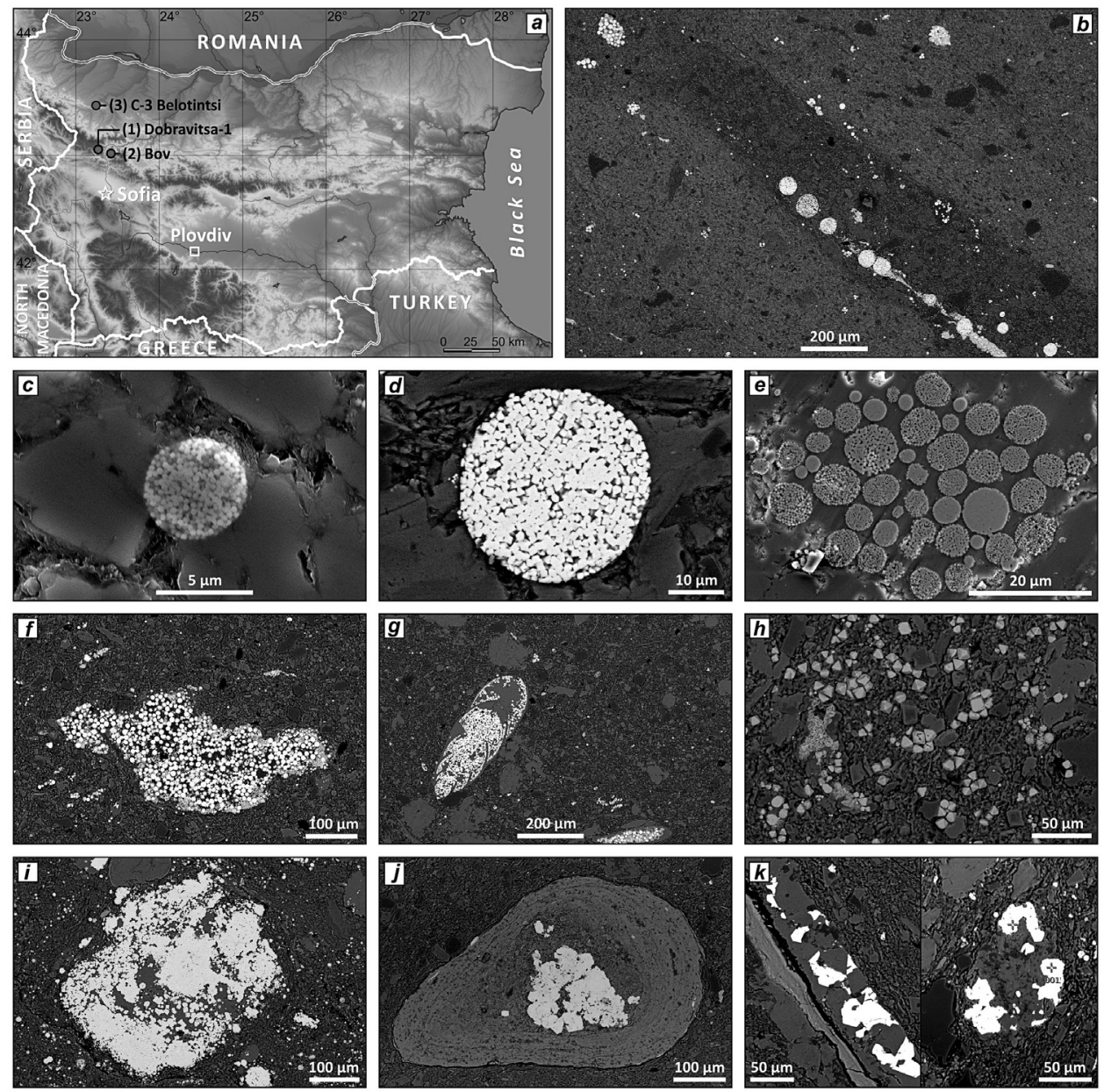

Fig. 1. Location map and selected backscatter SEM images of micropyrites from the Toarcian of Bulgaria: $a$, sketch map showing positions of study sections; $b$, low magnification overview of sediment fabric from section Dobravitsa-1 showing a composition of clay minerals, quartz silt grains and bright micropyrites from each of the designated types (upper Toarcian, Pseudoradiosa Zone, Levesquei Subzone); $c$, euxinic framboid from section Bov, lower Toarcian (Falciferum Zone, Serpentinum Subzone); $d$, oxic/ dysoxic framboid from section Dobravitsa-1, upper Toarcian (Pseudoradiosa Zone and Subzone); $e$, polyframboid with distant to weakly bounded pyrite clusters, showing different degrees of compaction of the microcrysts, from section Bov, lower Toarcian (Bifrons Zone, Lusitanicum Subzone); $f$, polyframboid lense (including both weathered and unaltered framboids) from section C-3 Belotintsi (upper Toarcian), euxinic and oxic/dysoxic framboids also occur; $g$, benthic foraminifera, containing abundant framboids, from section C-3 Belotintsi, lower Toarcian (Falciferum Zone and Subzone); $h$, abundant euhedral grains (microcrysts) of pyrite from section C-3 Belotintsi, Toarcian (Bifrons/Variabilis Zones); $i$, rounded bleb of pyrite, grown on a lithoclast, surrounded by a range of framboid morphologies, from section Bov, lower Toarcian (Tenuicostatum Zone); $j$, reworked iron ooid with crystal pyrite in the core, section Dobravitsa-1, upper Toarcian (Fallaciosum Zone); $k$, lithoclasts containing unaltered grains of chalcopyrite (left) and sphalerite (right) from the same section and level as the previous example 
of pyrites were identified: 1) euxinic framboids; 2) oxic/dysoxic framboids; 3) polyframboids; 4) non-framboidal diagenetic pyrites (see Fig. 1b-k). The euxinic framboids are small $(<5 \mu \mathrm{m})$ and closely packed spherical aggregates of uniformsized microcrysts, with a narrow size range, as defined by Wilkin et al. (1996). They usually appear from thin and discrete layers of finely laminated shales, with increased TOC content, from each of the studied sections. These framboids are particularly abundant in the rocks of the lower Toarcian Falciferum ammonite Zone and in the upper Toarcian Pseudoradiosa ammonite Zone (see Fig. 1b, c). The oxic/dysoxic framboids (Fig. 1d) correspond to much larger, spherical to subspheroidal aggregates $(5-30 \mu \mathrm{m})$, in which pyrite microcrysts often display evidence of compaction, but are less dense packing and have a wider range in the individual crystal sizes (cf. Wilkin et al., 1996; Wignall, Newton, 1988). These framboids are the dominant component in the pyrite fractions of most of the analyzed samples. The polyframboids (Fig. 1e) are coalesced and ordered pyrite aggregates of up to $30-60 \mu \mathrm{m}$ in size that contain spherical clusters of a few microns-sized microcrysts (cf. Wignall, Newton, 1988). Usually, the pyrite clusters appear to be weakly bounded, but in some individuals the clusters are fused with dense masses of extremely small crystalline pyrite. Polyframboids also comprise larger disordered framboid aggregates (lumpy to lenticular in shape), as well as various framboid infill entities and framboid clusters infilling benthic microfossils (Fig. 1f, g). This type is common throughout. The non-framboidal diagenetic type of pyrites is a persistent constituent of the pyrite populations. It is most common in section Bov, while in sections Dobravitsa-1 and C-3 Belotintsi it has narrower distribution. This type mainly consists of abundant euhedral microcrysts of pyrite (cubes, octahedra) (Fig. 1h), but fibrous and shapeless varieties, as well as large rounded blebs of pyrite also occur (Fig. 1i). The diagenetic pyrites were also noticed as inclusions in various allochems, including lithoclasts and reworked iron ooids (Fig. 1j). In addition to the main types of pyrites, it is interesting to note that in a few samples from the upper Toarcian of section Dobravitsa-1, resedimented subangular lithoclasts containing grains of sulphides (chalcopyrite, sphalerite) were observed (Fig. 1k). The EDS spectra taken on the recognized types of pyrites, as well as those on the sulphides, showed that they are generally not oxidized and retained their original content.

The bulk of the viewed framboids are typical examples of their kind but the pyrite populations also include morphologies, which require special attention and will be considered elsewhere. The framboid morphologies vary subtly from sample to sample, although it has been observed that at certain stratigraphic levels some types prevail over others. Euxinic framboids, with a diameter of less than 5 $\mu \mathrm{m}$, are seldom dominant, in contrast to the oxic/ dysoxic, of 30-60 $\mu \mathrm{m}$ in size, and the polyframboids, which are plentiful throughout. From this it can be concluded that upper- to lower dysoxic depositional settings prevailed in the sampled successions. A few shifts towards anoxic conditions, associated with narrow levels from both the lower Toarcian and the upper Toarcian, possibly exist, but further analysis of the framboid size distribution is needed to prove this firmly. These potential anoxic shifts, however, do not correlate either in the sections studied or with the available coeval data from elsewhere. Furthermore, the oxygen-poor settings indicated by the samples from the upper Toarcian strata appear to be more significant than those hinted at from the lower Toarcian.

Acknowledgements: This work is a contribution the National Science Program's "Environmental Protection and Reduction of Risks of Adverse Events and Natural Disasters", No. 577/17.08.2018, supported by the Bulgarian Ministry of Education and Science (Agreement No. DO 1-363/17.12.2020). We thank Dr George Lütov (University of Mining and Geology) for technical assistance with the SEM.

\section{References}

Bond, P. G., P. B. Wignall. 2010. Pyrite framboid study of marine Permian-Triassic boundary sections: A complex anoxic event and its relationship to contemporaneous mass extinction. - GSA Bulletin, 122, 7/8, 1265-1279; https:// doi.org/10.1130/B300042.1.

Metodiev, L., M. Georgieva, T. Stoylkova, E. Koleva-Rekalova. 2020. Redox levels of deposition across the Toarcian - trace element data from Bulgaria. - Rev. Bulg. Geol. Soc., $81,3,138-140$

Pugh, A. 2018. Palaeoenvironmental and Biotic Change through the Lower Jurassic in Bulgaria. Unpublished PhD Thesis, Univ. Leeds, Earth Surface Science Instл, School of Earth and Environment, 383 p.

Rickard, D. 2019. Sedimentary pyrite framboid size-frequency distributions: A meta-analysis. - Palaeogeogr., Palaeoclimatol., Palaeoecol., 522, 62-75; https://doi.org/10.1016/j. palaeo.2019.03.010.

Wignall, P. B., R. J., Newton. 1998. Pyrite framboid diameter as a measure of oxygen deficiency in ancient mudrocks. $-\mathrm{Am}$. J. Sci., 298, 537-552; https://doi.org/10.2475/ajs.298.7.537.

Wignall, P. B., R. J. Newton, M. E. Brookfield. 2005. Pyrite framboid evidence for oxygen-poor deposition during the Permian-Triassic crisis in Kashmir. - Palaeogeogr., Palaeoclimatol., Palaeoecol., 216, 183-188; https://doi. org/10.1016/j.palaeo.2004.10.009.

Wilkin, R. T., H. L. Barnes, S. L. Brantley. 1996. The size distribution of framboidal pyrite in modern sediments: An indicator of redox conditions. - Geochim. et Cosmochim. Acta, 60, 20, 3897-3912; https://doi.org/10.1016/00167037(96)00209-8. 